\title{
THE ADDRESS TERMS IN ENGLISH AND SELAYERESE: A SOCIOLINGUISTIC PERSPECTIVE
}

\author{
Irma Zavitri ${ }^{1}$ Hamzah Machmoed ${ }^{2}$, Sukmawati $^{3}$ \\ ${ }^{1,2,3}$ English Language Studies Postgraduate Program, Hasanuddin University, Makassar \\ irmazavitri@gmail.com \\ hmzmachmoed@yahoo.com \\ sukmamumu@yahoo.com
}

\begin{abstract}
This research aims to reveal the use of address terms in English and Selayarese based on situation and context and to understand the aspects that influenced the use of address terms in English and Selayarese. This study was analyzed through descriptive qualitative approach. The English data were taken from some conversational events in the movies while the Selayarese data were taken from the participant observation, depth interview, and field notes. The data requirement is focused on the address terms performed by English (American) and Selayarese community. The results of this research indicate some kinds of address terms occupied in both languages namely: 1) pronouns, 2) kinship terms, 3) title and professional terms, 4) religious terms, 5) nobility terms, 6) terms of endearments. The difference from both languages appeared in which the nobility terms and teknonyms was not accommodated in English data. Another difference is Selayarese use certain address terms to call cousin and nephew or niece. Beside that there are also some similarities from both languages in which they use first name to call their mother, father, grandfather and grandmother and both languages applied endearments to address someone. It was also found from the data that there are some aspects that influenced the use of address terms in English and Selayarese, namely: 1) age difference, 2) social situation, consisting formal and non formal situation, 3) social status, consisting achieved and ascribed status, 4) social distance or degree of intimacy.

Key words: address terms, politeness theory, descriptive-qualitative
\end{abstract}

\section{INTRODUCTION}

Address forms are words that are used by speaker to address their interlocutor while they are communicating to them (Fasold, 1990: 1-2). As an important feature of interface between language and society, address forms can provide valuable sociolinguistic information about the interlocutors, their relationship and their circumstances. The most influential study of address form and social relationship was proposed by Brown and Gilman. They proposed two uses of pronouns led by two semantics; they are power and solidarity (Fasold, 1990: 3). The existence of power and solidarity in speaking community will determine the address forms choice.

Noting that many of the researchers have proposed the study of address terms both in and out of Indonesia, still the writer believes that there is an aspect that remains unanalyzed. Each place has its own way to address someone and it is related to the culture recognized in that place. As mentioned previously, although these address terms have taken a huge attraction for the researchers to be analyzed and may be plausible, it is nevertheless incomplete more over if we compare with another language. In Indonesia itself there are many researchers who studied about address terms, but not every language in Indonesia has been analyzed in the terms of address forms.

In Selayar community the writer often find the member of the community have conflict because of address terms usage whether it is open conflict or close conflict. They are blaming each other about the use of proper address terms and which one is polite and impolite. They 


\section{0 | JURNAL ILMU BUDAYA}

Volume 6, Nomor 1, Juni 2018

argue about who and why certain people should use certain address terms or should be addressed particularly. In Selayar, as far as the writer knowledge there is no enough information about the address terms, might be the reason why they keep arguing about this matter. The writer hardly found another researcher writing about address terms in Selayar and therefore it will be very interesting and informative to do something to clarify these address terms.

There have been some researchers studied about the politeness strategies. The first, Meniwati (2014) who conducted a research on Interplay between social status and address terms in Sambas Malay: A sociolinguistics study. The result shows that the address terms in Sambas Malay are numerous, then classified into forms that based on the functions. The most common address forms that are used are the common address terms (C) and honorific address terms $(\mathrm{H})$. These functions in three sort of dyadic pattern, that are the mutual $\mathrm{C}$, the mutual $\mathrm{H}$, and then non-reciprocal $\mathrm{H}-\mathrm{C}$. second, Ijadhalid (2016) who conducted a research on Power relation and address terms in English and Buginess : A politeness study. The results of the research indicate some kinds of address terms occupied in both languages namely 1) pronouns, 2) kinship terms, 3) title and occupational terms, 4) religious terms, 5) nobility terms 6) teknonyms, and 7) terms of endearment. The difference in both languages appeared in which the nobility terms and teknonymies are not accommodated in English American while the use of endearment terms is not usual in Buginese. It is also found that the age difference, social situation, social status, social distance or degree of intimacy, equality, and marital status among the speakers determine the pattern of speech concerning the power relations.

Many previous studies explained about address terms but there is still few research about address terms and politeness in
Selayarese. Therefore this research is aimed at finding out the address terms and aspect that influence the use of address terms in English and Selayarese.

\section{RESEARCH METHODOLOGY}

\section{Research Design}

This research aims to analyze how Address terms in English and Selayarese are carried out, and what aspects tend to influence terms the use of address terms in English and Selayarese.

Furthermore, descriptive qualitative method applied in this research in order to fulfill the aims mentioned above. It was done by that way because the whole package of social situations including space, actors, activities, objects, and the sequencing that take place over time were analyzed (Spradley,1980: 40).

\section{Sources of Data}

The data taken in this research was the observation results and recordings of everyday utterances of Selayarese, as this was a field research. Besides, the researcher also gained the information about the social relations including the personal information of the actor from the informants. personal life of them.

For English data, researcher used the form of Address in English through translation and for addition took English movies as references. The researcher took only Address terms utterances to be analyzed. The researcher did library research to strengthen the analysis of data taken from the field.

\section{Methods of Collecting Data}

In collecting data, the researcher employed some methods. The data were taken from Selayar people and the researcher used direct observation by recording the conversation then taking note and interviewing.

\section{Methods of Analyzing Data}

The selected data were transcribed. By doing this, the researcher could easily analyze the data. After transcribing the 


\section{1 | JURNAL ILMU BUDAYA}

Volume 6, Nomor 1, Juni 2018

selected data, they were translated into English. It is aimed to let non-Selayarese people to understand what the conversation is about. Besides, this research was conducted as the object of English Language Studies, introducing data gathered to other English-based scholars. After translated into English the researcher did morpheme by morpheme analysis to make sure the equivalence of the data translated. Making the classification of address terms in English and Selayarese based on their differences and similarities. Describing the forms of address terms in English and Selayarese and classifying the aspects influence the address terms used in both languages. Finally, data verification was employed to draw conclusion that answered all the questions proposed in this research.

\section{FINDINGS}

\section{To address using Second pronoun}

A: Baji' mu lungang ta Opu?Ditte, Maing muki anrio?

(Is your pillow okay now Opu? Have you taken a bath?)

B: kau ngura sallo konjo ko lau'?

(Why did you stay long there)

A: sallo kang accari' carita

(We took time talking)

A talk between granddaughter and her grandmother, it is identified that there are two kinds of pronouns used by the participants to address their interlocutor. Using kau as a subject in her sentence to address A, while $\mathrm{A}$ used ditte to address B. A used the polite form to address her grandmother $\mathrm{B}$, while $\mathrm{B}$ used impolite form to address her granddaughter, A.

\section{To address Mother}

A: ulung ku sampa pa'risi Ti'no. (my head is always painful, Ti'no)

$B$ : I sitti amang maingi antama ri balla garring bede?

(Sitti amang has been hospitalized, right?)

A: u, gele pa ko minang mange ri saponna?

(yes, have not you been visited her?)
B: gele pa.

From the data, we can see that the child address his mother by her nickname, Ti'no and use the pronoun you (kau) but it is categorized as polite term. And the child also said "u" to say "yes" in impolite way which in some hierarchical culture it will be considered rude but in Selayarese it will be fine.

3. To address

\section{Grandmother/grandfather}

A: sukku na ka I Jomok lakaluppai KTP na

(it is so frustrating to know that Jomok forgot her ID card)

B: Allah

(God)

The previous conversation is a statement from a grandson to address his grandmother. Another example of conversation from a grandchild to address grandparent can be seen as follow:

\section{To address Uncle/aunt}

A: I kau Purina sanna kulara mu

(you, Purina is so stingy)

B: na ngura mu kua, kamanakang?

(why did you say so?)

A: injo anjoro sibatu batu juwa sanna mamo pa' nyereng nyereng mu.

(it is only a matter of one coconut and you are so chatterbox).

Furthermore, many people address their uncle by saying Patta +nickname/shortname or addressing them by using Atta+ nickname/shortname. People in Selayar tend to use noble title name such as patta/atta to call their uncle/aunt to show respect and the status in the society.

5. To address cousins

A: maimmu mu kikisi tampa' mu pindu siang?

(have you fenced your land, pindu siang?

B: u, I badulu ku suro anjama. Rua ngallo juwa i maiimmu, pindu. 


\section{2 | JURNAL ILMU BUDAYA}

Volume 6, Nomor 1, Juni 2018

( I just asked Badulu to help out, and it was only for two days work, Pindu)

In Selayar the people use the term first cousin, second cousin, third cousin, fourth cousin, etc. so when they address their cousins it is based on that level. The example above is to address the second cousin and they use second pronoun $-\mathbf{m u}$ or-ko since they are same age.

\section{Endearment terms}

A: ana' Opu muliang mako.Nguraji passikolaang $m u$ ?

(anak' Opu, you came back from school, ya? How's the school?)

B: biasa, lohe tugas battu ri Pak Guru. (well, just so so. A lot tasks from the teacher).

In Selayar, it is quite common to call someone with the noble title including to address the children in hoping that in the future they will be as great as their ancestor so it is such a prayer. Certain family uses noble title name that is taken from the ancestor name or great grandparents name as the sign of honor and remembrance.

\section{Professional terms}

A: Pak Lingkung, ngura mu passikola'an injo?

(how's the school, Pak Lngkung?)

B: tideppa ata'na, ampa pi la mange ammalli

(they just want to buy them)

There is also a profession called Pak Lingkung that is still used till today. It is an abbreviation of Malay language lingkungan or in English means environment. It is a chief of two villages and in the past it has a very powerful force to move people.

\section{Religious address terms}

Religious insight becomes a significant influence for the use of address terms in Selayar. A person who has religious insight or experience has a higher position in society than one who does not or less. It is manifested through the use of address term. The table above presents some address terms concerning with the religious affairs. As example below:

A: la kuwa I baso Jidu Pak Imamja bede la riye'.

( Baso Jidu said, Pak Imam will come)

$B$ : o appa konjo $i$ ?

(Is it?)

A: iyo'

(Yes, sure)

B: baji'na mo pale ampa Pak Imamja la lasambajangi Oри ти.

(It is goo knowing that Pak Imam will lead the prayer for your Opu's corpse.

\section{Nobility address terms}

Look at the following illustrations. It is the conversation between granddaughter and her grandmother. Granddaughter used noble terms, $O p u$.

A: sikurayya na lampa ki Opu Ti'no?

(When will you go there Opu Ti'no)

$B:$ gele ma. Kale kalenna jua la lampa.

(I won't. she will go by herself)

A: Nangura Opu Ti'no?

(Why is that?)

$B$ : ka gele ji malla bede

(Because she is not scared)

\section{DISCUSSION}

The aim of the research is to analyze and to compare English and Selayarese address terms used in daily communication. The researcher found some phenomena about address term in English and Selayarese from the data gathered.

Address terms is one of the observable social phenomena of language used within Selayarese community. It characterizes and symbolizes the users (speakers and interlocutors) of Selayarese in all settings of language used. This address terms have its own characteristics which make it different from other communities.

English address terms of kinship terms such as grandfather, grandmother, great grandfather, father, mother, uncle aunty, so, daughter, etc are used in family and 


\section{3 | JURNAL ILMU BUDAYA}

Volume 6, Nomor 1, Juni 2018

relative relation. There are equal to Selayarese such as Dato', Opu, Bapak. According to Yassi (2012: 9) old people as a superior tend to use more casual address term then young people as inferior. Therefore, solidarity politeness system is asymmetry. However, it is different from Selayarese. There are some people address his/her mother, grandmother with nickname it is because of habit and intimacy.

In Selayarese, there are other address terms that different from English. Address terms in Selayarese are unique which has different characteristics that distinguish them from other communities and languages. The address terms are based on ancestors name (talli, halijah, Malluru, kasissili, etc), based on skin color (bongko etang, bunga le'leng, bolong, etc), based on body posture (langkasa' ulu, kapi toli, ca pende', etc). They use it without mentioning his/her real names. In other cultures, when we address people based on their physical appearance is considered as impolite term. It will make the hearer feel offended because it can threaten the hearer's face. It is proposed by brown and Lavinson (FTAs). However in Selayerese it is categorized polite as a way to show intimacy or solidarity.

One of the striking different is the use of second person pronoun in both languages. In Selayar, when we address people in family and non family relationship with different second personal pronoun, it depends on the situation whether we will use polite or impolite personal pronoun. While in English, we could not find any separation regarding this personal pronoun. English only has one personal pronoun for second person pronoun, it is you. However in Selayarese they have second pronoun such as ditte to address politely and $\mathbf{k a u} / \mathbf{k o}$ to address impolitely. There are also second pronoun $-\boldsymbol{m u}$ to address someone younger and lower status and second pronoun $-\boldsymbol{t a}$ to address someone older and higher in position /rank.

Endearments terms in Selayarese are often used like in English too. In Selayar the use of endearments especially are for daughters such as calling with nak'/ anak, Anak bulaeng or anak Opu.

Selayar people consider the social status and age difference have higher portions for the asymmetry address form and relationship among the speakers than the other social aspects. That is because the people with higher status and older age are compulsory honored. In the other word that the people with the high social status and older has more power in a conversation. Those considerations will not be sifted by the consideration of other social aspects. In addition that particular address terms above will be used in the whole consideration of the social aspects especially for the address terms of nobility that showing the social status.

Some other aspects like social situation and social distance showed potentially to produce the symmetric relationship through the use of address terms. It will be appeared of course when the consideration of age difference and social status are ignored.

\section{CONCLUSIONS}

From the findings and discussion, the researcher draws conclusions that the Selayarese which has the hierarchical culture pattern is quiet interesting since the address terms used has some similarities with English which is Egalitarian culture. In Selayarese some people can address her mom by name but still considered polite. One of the striking points is that in the nobility terms the aspect is not again about the ascribed status but shifting to achieved status such as wealth and education. This phenomenon can cause conflict and it is why people need to be wise and objective in reacting about this situation. The researcher hopes that this kind of research will be continued by further researchers to find out more phenomena in 


\section{4 | JURNAL ILMU BUDAYA}

Volume 6, Nomor 1, Juni 2018

sociolinguistic study or cross cultural pragmatics. Besides, it is important to find out the variation of the address terms used all over Indonesia and hoped to be one of the sources for other researchers who want to do research on address terms in other languages.

\section{BIBLIOGRAPHY}

Anderson, Katie. 2010. Film as a Reflection of Society: Interactional Marriage and Stanley Kramer's: "Guess Who's Coming to Dinner" in late 1960's America. Vol 4 SURG.

Djatmika. 2011. Pemberian Nama Panggilan dalam Masyarakat Jawa: Sebuah Studi Kasus Di Surakarta. Makalah Pada Kongres Internasional Masyarakat Linguistik Indonesia (KIMLI). Surakarta: Universitas Sebelas Maret Surakarta.

Fasold, Ralph. 1990. Sociolinguistics of Language. Cambridge: Basil Blackwell Inc.

Khalid, Ijad. 2016. Power relation and address terms in English and Buginese: A politeness study. Makassar: Hasanuddin University.

Maulud, Ismail. 2009. Terms of address in English and Tidorenese Languages: a sociolinguistics study. Makassar: Hasanuddin University.

Meniwati. 2014. Interplay between social status and address terms in Sambas Malay: A sociolinguistics study. Makassar: Hasanuddin University.

Spradley, James P. 1980. Participant Observation. New Jersey: Holt Rinehart and Winston.

Sugiyono. (2014). Metode Penelitian Kuantitatif Kualitatif dan $R \& D$. Bandung: Alfabeta.

Wardhaugh, Ronald. 2001. An Introduction to Sociolinguistics. New Jersey: Blackwell Publishing.

Yassi, Abdul Hakim. 2012. Model Sistem Kesantunan Bahasa Makassar: Mengkaji Keuniversalitasan Teori
Kesantunan Brown \& Levinson.

Published Paper on International Congress of Vernaculars in South Sulawesi. 